\title{
ARBITRAL CLAUSES / some comparative observations
}

\author{
by E.H. Hondius*
}

\section{INTRODUCTION}

On 1 September 1981 the local court (kantongerecht) of Alphen aan den Rijn decided on a case in which a contracting party, a commercial enterprise, invoked an arbitral clause in order to prevent the court from deciding the case on its merits. In accordance with Dutch case law, the defendant's reliance on the arbitral clause was allowed and plaintiff's claim was denied. ${ }^{1}$

The local court decision may be in accordance with the law as it is, but it might well be contrary to the law, as set out in the New Civil Code, which will enter into force by $1985 .^{2}$ However, the way in which the new law will treat arbitration clauses is still uncertain. In this contribution, I shall try to present the arguments advanced in favour of or against legislation on standard arbitral clauses. The discussion in The Netherlands with regard to this question has recently been enlivened by the proposed legislation on unfair contract terms.

Since similar legislation on standard contract terms has already been enacted in several other European countries, it seems worthwile to study how these countries have approached the specific problems related to arbitration clauses. Sweden provides us with the most interesting development in this respect. In the United Kingdom, it is not the Unfair Contract Terms Act, but rather the Arbitration Act 1979 which is of interest: some recent cases reveal how arbitral clauses can be constructed. The construction of such clauses constitutes the second subject of this contribution.

The German Federal Republic, which produces by far the largest number of court decisions and especially legal publications in the area of standard contract terms (Allgemeine Geschäftsbedingungen), has surprisingly little to teach us with regard to arbitral clauses and will therefore not be dealt with in this contribution. Nor will French law be considered, though for a different reason. In France, arbitral (compromissoire) clauses have long been considered unlawful except in commercial cases. Development there has been in a different direction: towards more freedom ${ }^{3}$; so far, the legislation on unfair contract terms has not had any influence in this respect.

* Professor of Civil Law, Utrecht University; Member of the Board of Editors.

1. Kantongerecht Alphen aan clen Rijn 2 September 1981, Praktijkgids 1981 no. 1652 (Zorab v. B.V. Koetsier Hekman van Zutphen).

2. See my article on 'Recodification of the law in The Netherlands' in NILR 1982, 348.

3. Decree of 14 May 1980 JO 1980, 1238-1240. Cf. Thomas E. Carbonneau, The elaboration of a French court doctrine on international commercial arbitration; a study in liberal 
In Italy, a draft bill on standard contract terms ${ }^{4}$, which was presented at a conference in Fiuggi in 1981, provides an interesting analogy to the Dutch bill, at least with regard to arbitration. ${ }^{5}$ The future of this draft is still uncertain, however, and the Italian provision on arbitration will therefore not be dealt with.

The Dutch discussion on how to handle arbitral clauses necessarily reflects the approach to arbitration itself. I shall therefore first try to give a summary of the advantages and disadvantages of arbitration, as set out in Dutch legal writing.

Before going into the advantages and disadvantages of arbitration and other forms of settlement of disputes out of court, I will suggest the relative importance of Dutch arbitration as compared with the settlement of conflicts through the courts.

\section{ARBITRATION: THE PRESENT SITUATION IN THE NETHERLANDS}

What role does arbitration play in The Netherlands at present? No comprehensive statistics are available on the exact number of arbitrations, but we do possess some figures which give an indication of its use.

Modern commercial arbitration dates back to the second half of the nineteenth century. ${ }^{6}$ Among the aims of many of the then newly-formed trade associations was the foundation of private arbitration tribunals for the settlement of conflicts. These tribunals were very welcome to Dutch commerce, since - unlike countries such as Belgium and France - the Netherlands did not have any tribunaux de commerce comprising both judges well versed in the law and trade experts.

Arbitration became very popular in the first two decades of this century. In the period from 1900 to 1913 , the number of commercial cases settled by the Rotterdam District Court remained on average 300 per year, whereas the number of arbitral awards deposed at the same court rose from 20 to 1,330 per year. ${ }^{7}$

civilian judicial creativity, Tulane Law Review 1-62 (1980). Regarding the Decree of 12 May 1981 JO 1981, 1380 see B. Goldman, La nouvelle réglementation française de l'arbitrage international, in: The Art of Arbitration/Liber amicorum Pieter Sanders, Deventer 1982, pp. 153-174.

4. Testo-base di discussione per il convegno di Fiuggi sulle condizioni generali di contratto del 5-6 giugno 1981.

Regarding binding recommendations see also C.M. Barone, Considerazioni sul procedimento arbitrale e sugli aspetti processuali dell'arbitrato irrituali, in: I processi speciali, Napels 1979 , p. 57 et seq., especially p. 68 et seq.; G. Collura, Manifesta inequità e arbitrato irrituale, Revista trimestrale di diritto e procedura civile 1981,pp.89-139; and Corte di cassazione 12 December 1981, Foro italiano 1982, I, p. 1062.

5. According to the draft art. 1341/2 'Sono nulle, anche se approvate specificamente per iscritto, le clausole che alterano l'equilibrio del contratto in pregiudizio dell' aderente senza giustificarsi obiettivamente nell' economia dell'affare e, in generale, le clausole non conformi alle regole della correttezza, anche professionale, o all' equità'.

The draft art. 1341/2 proceeds with a 'grey' list of clauses - 'A titolo esemplicativo sono reputate nulle, salvo che risultino giustificate obiettivamente nell' economia dell' affare . . .' am ong which the arbitration clause.

6. Some authors give 1872 as the starting point - B.D.H. Tellegen, Handelingen Nederlandsche Juristen-Vereeniging 1872, II, p. 152 and A.S. Fransen van de Putte, Handelingen Nederlandse Juristen-Vereniging 1968, I, p. 79, 88. Others sometimes mention an earlier date.

7. W. Nolen, Zijn wijzigingen in de bepalingen van het Wetboek van Burgerlijke Rechts- 
After 1919, however, the annual number of arbitral awards settled at a much lower level and was rapidly overtaken by the number of court decisions. By 1968 , the number of arbitral awards was estimated to be some $5 \%$ of all district court decisions in civil matters - family law, bankruptcy, and expropriation cases are not included - (in Rotterdam, this percentage was estimated to be $10 \%$ ). ${ }^{8}$ Since 1968 , the number of arbitral awards appears to have grown once again, not only in the area of trade, but also through the spread of arbitration to areas other than the traditional ones, in particular to construction. ${ }^{9}$

However, another development is taking place which from a purely quantitative viewpoint is even more important. The growth of consumer protection had led to the foundation of a steadily increasing number of geschillencommissies (complaints boards), usually composed of a member appointed by trade or industry, a member appointed by a consumers' organisation, and an independent president. These geschillencommissies do not lay down their decisions in the form of an arbitral award, but as a bindend advies. The literal translation of this peculiarly Dutch concept will be obvious to English-speaking readers: it is a binding recommendation. "Binding" in the sense that the parties to a contract who have submitted the settlement of their dispute to the geschillencommissie, are contractually bound and not bound by way of civil procedure: a bindend advies, unlike arbitration, does not entitle the creditor to an execution; it is a recommendation to the parties on how to solve their dispute. ${ }^{10}$

In theory therefore, arbitration and bindend advies are two distinct concepts, the one belonging to civil procedure, the other being of contractual origin. In practice, arbitration and bindend advies are not so far apart. Although a binding recommendation does not by itself constitute an executory title, a court will usually consider it binding and demand its enforcement.

It should be remarked that the bindend advies concept is not an invention of the consumer protection movement, nor is it a recent phenomenon. Like modern commercial arbitration, it originated during the second half of the nineteenth century in the construction industry. ${ }^{11}$ By the 1970's, the construction industry had almost wholly moved from binding recommendations to arbitration, but then the geschillencommissies came into being. In 1979, as many as 2,715 binding recommendations were submitted to the five geschillencommissies operating under the auspices of the Stichting Consumentenklachten. ${ }^{12}$

vordering omtrent de rechtspraak door scheidslieden, mede in verband met de toeneming van vaste scheidsgerechten, wenschelijk? Zoo ja, welke? Handelingen Nederlandsche JuristenVereeniging 1919, I, p. 1, 154.

8. A.S. Fransen van de Putte, Dient de wettelijke regeling omtrent arbitrage te worden gewijzigd? Handelingen Nederlandse Juristen-Vereniging 1968, I, p. 79, 153 (data collected by J. Knottenbelt).

9. See M.A. van Wijngaarden (ed.), Vijfenzeventig jaar bouwarbitrage 1907-11 april - 1982, Zwolle 1982 .

10. See P.A. Stein, Chapter 14, Civil Procedure, in: D.C. Fokkema et al. Introduction to Dutch law for Foreign Lawyers. Deventer 1978, p. 231, at p. 256.

11. M.A. van Wijngaarden, De Nieuwe A.V., thesis Vrije Universiteit, Deventer 1979.

12. Stichting Consumentenklachten, Jaarverslag 1979, p. 5. 
In the New Civil Code which is expected to enter into force in 1985, the bindend advies will have a permanent basis. Title 7.15 on the vaststellingsovereenkomst ${ }^{13}$ is explicitly meant to apply to binding recommendations as well.

One form of arbitration which is not now prevalent in The Netherlands is compulsory arbitration or arbitration provided for by law. A French law of 1790 for instance provided for compulsory arbitration in family and commercial matters ${ }^{14}$, but this law was not introduced in the Netherlands in the nineteenth century, nor was the German concept of Schiedsmann ${ }^{15}$ or the modern form of arbitration by a court registrar as applied in the United Kingdom. ${ }^{16}$

\section{ADVANTAGES AND DISADVANTAGES OF ARBITRATION ${ }^{17}$}

Why should two contracting parties submit their disputes to arbitration or to other forms of settlement out of court, instead of to a state-appointed judge? Several reasons are usually advanced, such as the expertise of arbitrators, the swiftness and the informality of the arbitration procedure and the alleged possibility of reaching more equitable settlements. On the other hand, the high cost of arbitration, the (usual) absence of appeal, and the surprise element of arbitration clauses are often seen as disadvantages of settlement out of court. In this paragraph, I will set out these advantages and disadvantages in some detail, illustrating them with some recently compiled data. ${ }^{18}$

One advantage, which arbitration almost undoubtedly has, is the technical expertise of arbitrators in their trade. This expertise does not only relate to such matters as the composition, the nature and the quality of goods or services, but also to the usages in the branch of trade concerned. The ordinary court does not possess this specialised knowledge and therefore will often have to call in outside experts.

Against the advantage of expert knowledge of technical matters, we should set the possible disadvantage of a lack of legal knowledge. Unlike the courts, an . rbitration tribunal is not necessarily equipped with a member or a registrar who is learned in the law. In practice, however, most arbitration tribunals have a

13. See the contribution by W. Snijders in this volume.

14. See I. Delbrouck, Arbitrage in historisch perspectief, in: A. Boehlé et al., Arbitrage, Ghent 1973, p. 81, at pp. 93-94.

15. G. Bierbrauer, J. Falke, K.F. Koch, Conflict and its settlement: an interdisciplinary study concerning the legal basis, function and performance of the institution of the Schiedsman, in: M. Cappelletti, J. Weisner (eds.), Access to Justice, II, Promising Institutions, Alphen aan den Rijn/Milan 1978, I, p. 39 at p. 48.

16. G. Appleby, Small Claims in England and Wales, in: M. Cappelletti, J. Weisner (eds.), Access to Justice, II, Promising Institutions, Alphen aan den Rijn/Milan 1978, II, p. 683 at pp. 743-754.

17. This paragraph is partly based on my contribution 'De toekomst van de arbitrage', in: Advocatenblad 1981, pp. 151-156.

18. Harmonisatie van Standaardvoorwaarden in de Bouw, Rapport van de Werkgroep Standaardregelingen in de Bouw (hereafter cited as Rapport), Deventer/Alphen aan den Rijn 1981, Appendix 6 by J.M. Schoenmakers. 
registrar who is learned in the law. The statutes of the Stichting Consumentenklachten require that the president of a geschillencommissie is learned in the law. Conversely could an ordinary court be supplemented with lay judges who are expert in a specific trade? Belgian and French experience shows that this should be possible. Dutch experience with lay judges is less positive. As has been pointed out, such lay judges will often be appointed on the recommendation of a professional organisation and will therefore often be more likely to represent professional interests than to be mere experts. ${ }^{19}$

A second advantage which is attached to arbitration is the informal procedure and the possibility of equitable judgments. Although this advantage does still exist, it no longer seems of primary importance, as court procedures have become far less formal than they were previously. ${ }^{20}$ Arbitrators are not bound by the rules of evidence, but these rules have become so flexible that the difference in this respect between court adjudication and arbitration is now rather small. Finally, arbitrators should apply equity ${ }^{\mathbf{2 1}}$, but once again practice shows that this makes little difference, as common law has developed so many constructions to reach equitable judgments that the harsh pacta sunt servanda is no longer considered to be the last word on the matter. ${ }^{22}$

Rapid procedure is the third advantage which is usually ascribed to arbitration. Statistics are now available, which support this contention at least in some areas of arbitration. In the construction industry, the average time between bringing a case before the arbitration tribunal and receiving the arbitral award ranges from eight to fifteen months for the various arbitration tribunals. ${ }^{23}$ For the geschillencommissies of the Stichting Consumentenklachten, the number of months varies from 3.5 to $7.5 .^{24}$

Corresponding statistics on court adjudication are unfortunately not available. Some years ago, some $70 \%$ of all defended actions - family affairs excepted were dealt with within twenty-two or twenty-four months. ${ }^{25}$ It is not possible to compare these figures with any great precision. Moreover, one should always reckon with the (theoretical) possibility that an arbitral award will be annulled by a court. ${ }^{26}$ Nevertheless, the available data do at least suggest that arbitration is more rapid than court procedure. ${ }^{27}$

19. O.A.C. Verpaalen, Hart en nieren van de Nederlandsche Burgerlijke rechter, Zwolle 1974, pp. 95-96.

20. J.L.M. Elders, The use of conciliation for dispute settlement in Dutch civil procedure, in: Netherlands Report to the Xth International Congress of Comparative Law, Budapest 1978, Deventer 1978, pp. 159-170.

21. According to art. 636 Wetboek van Burgerlijke Rechtsvordering arbitrators should either apply the law or equity. The law sees the latter possibility as an exception, but in practice the terms of reference always provide that arbitrators should apply equity.

22. See the contribution by J.L.M. Elders in this volume.

23. Rapport (see footnote 18), p. 280, 287, 293.

24. Stichting Consumentenklachten, Jaarverslag 1979, p. 9.

25. P. Zonderland, Privaatrechtspleging in grondtrekken, Zwolle 1977, p. 255.

26. N.A. Koedam, Tijdschrift voor arbitrage 1980 , p. 65 , at p. 70 .

27. This experience does not seem to be universal. Cf. for instance the Chairman of the (English) Law Commission, Mr. Justice Kerr, in Journal of Business Law 1980, p. 178: 'The 
A final advantage of arbitration which I should not omit to mention (there are, of course, several other advantages) is that the procedure and outcome may be kept secret. From the point of view of legal development such secrecy is a disadvantage, though this can be overcome by anonymous publication. ${ }^{28}$

Is arbitration also cheaper? Here, a distinction should be made between arbitration proper and non-arbitral conflict settlement out of court. There is some evidence that the former is more expensive - at least for the parties concerned than court procedure, and the latter less expensive. Arbitration is often more expensive for the parties concerned, because the costs of the arbitration tribunal must be borne by them. In the construction industry for instance the average costs of arbitration itself (usually to be paid by the loser, costs of legal aid not included) some years ago varied from f. 3.600,-- for the Raad van Arbitrage voor de Bouwbedrijven in Nederland to f. 2.000,-- for the Arbitrage-Instituut Bouwkunst. ${ }^{29}$ These costs are high compared to the cost of litigation before an ordinary court (most of the expenses of which are furnished by the State). On the other hand, the arbitration tribunal will rarely have to call in the testimony of experts. Secondly, arbitration does not necessarily require legal counsel (although in practice many contracting parties retain an attorney in arbitral litigation).

In contrast, the settlement of conflicts by means of binding recommendation is often quite inexpensive for the contracting parties. Usually, no more than f. 50,-is demanded from the consumer (this will only be forfeited if he loses). In practice, the costs of maintaining a geschillencommissie will be far higher, but these costs are mainly borne by the state and by trade and industry.

A major disadvantage of both arbitral and bindend advies clauses is that they are often concealed in the small print of a contract and then take the other party by surprise. This problem does not only occur with regard to arbitral and binding recommendation clauses. What makes these clauses even harder to accept for the other party, however, is that from his point of view the enterpreneur not only drafts his own law (the standard form contract), but he also decides on the conflicts as to this "law". This point of view is of course erroneous, in the sense that the private tribunals involved are most often unbiased, quite representative and of high quality. Nevertheless, the suspicion of a biased attitude will persist, especially when the arbitral or bindend advies clause does not offer the other party the possibility of opting for settlement of the conflict by an ordinary court.

Finally, arbitration often does not allow appeals to be made. Appeal from arbitral awards to the courts is virtually unknown in The Netherlands (unlike in the United Kingdom) and appeal to appellate arbitration tribunals exists only in some trades and industries. In the construction trade further problems arise when,

only merit of many arbitration clauses currently in vogue, if one is cynical about them, is the fact that they provide a great incentive for settlement. Indeed, in many cases it ultimately turns out that it is virtually impossible to obtain an enforceable award within a reasonable time at reasonable cost'.

28. Thus, for instance, the T.M.C. Asser Institute for International Law in The Hague collects and classifies arbitral awards resulting from international trade in anonymous form.

29. Rapport (see footnote 18), p. 276, 286, 291. 
in a conflict involving three or more parties various arbitration tribunals may be called upon to settle the conflict between two of the parties concerned. ${ }^{30}$

The balance of the several advantages and disadvantages of conflict settlement out of court will differ, according to the importance one attaches to these elements. In my opinion, this method of conflict settlement has some obvious advantages in several areas, such as international trade and consumer contracts. Some disadvantages seem difficult to overcome, but others might conveivably be set aside. The latter category includes the problem that arbitration is often 'agreed' upon in a surreptitious way.

\section{THE SWEDISH RECORD}

Sweden was among the first of the European countries to enact legislation in the area of unfair contract terms. The control system, with its Consumer Ombudsman and Market Court, has proved to be effective. Swedish substantive law, however, is much less specific than more recent legislation on unfair contract terms, such as the German $A G B$-Gesetz and the Austrian Konsumentenschutzgesetz. When dealing with arbitral clauses, Swedish courts have therefore had to resort to the general clause (Generalklausel) contained in the unfair contract terms legislation, rather than to a more specific provision dealing with arbitral clauses.

Some recent cases illustrate the Swedish approach to arbitral clauses in standard form contracts. In Designern Carleric Göranzon v. Skandinaviska Aluminium Profiler Aktiebolaget ${ }^{31}$ the Högsta Domstol (Supreme Court) held that a company could not make use of an arbitral clause contained in its general conditions. The other contracting party was a freelance graphic designer, who himself acted in a professional capacity. This was probably the reason why in two lower instances the company was held to be entitled to invoke the arbitral clause, when the designer sued the company in court. The Högsta Domstol, however, decided in favour of the designer, on the grounds that he was inexperienced, needed the goods ordered, and had no alternative but to order them from the company in question.

In a more recent case, Tureberg-Sollentuna Lastbilcentral ek.för v. Byggnadsfirman Rudolf Asplund Aktiebolaget, ${ }^{32}$ the Högsta Domstol decided in favour of the company which invoked its arbitral clause. Although the said company had neglected to send the other party a copy of the general conditions which contained the arbitral clause, it was nonetheless considered to be entitled to avail itself of the clause, one of the major considerations being that the other party it-

30. Rapport (see footnote 18), p. 206 et seq.

31. Högsta Domstol 1 November 1979, Nytt Juridiskt Arkiv 1979, 666, Nordisk Domssamling 1980, 616 .

32. Högsta Domstol 12 February 1980, Nytt Juridiskt Arkiv 1980, 46, Nordisk Domssamling 1981, 167. 
self used general conditions containing an arbitral clause in its commercial dealings. ${ }^{33}$

On what ground was the arbitral clause considered to be inapplicable in the first case while it was applied in the second case? The Swedish Contract Law (Avtalsvillkorslagen) contains a provision, which gives ordinary courts the power to adjust or declare unenforceable any contract term which is found to be unreasonable (para. 36).

Although the wording of this provision is in general terms, it is clear from its legislative history ${ }^{34}$ that it was introduced in the aftermath of an important piece of consumer protection, the Act prohibiting improper terms of contract (Lag om förbud mot oskäliga avtalsvillkor). ${ }^{35}$ Under section 1 of this Act, the Market Court may issue an injunction prohibiting a tradesman from henceforth using an improper contract term. The court has used this power, inter alia, to prohibit the further use of arbitral clauses in consumer contracts. The Swedish Arbitration Act (Lag om skiljemän) ${ }^{36}$ contains a mandatory provision with regard to consumer contracts. Para. 3a provides that arbitral clauses are not enforceable against consumers when the amount in litigation is less than the jurisdictional amount of the Small Claims Act (Lag om rättegang $i$ tvistemal om mindre värden). ${ }^{37}$ The purpose of this provision is to ensure that the simplified procedure available under the Small Claims Act is not denied to consumers. ${ }^{38}$ As a result, in the case of Kvissberg \& Bäckström Byggnads $A B^{39}$, a supplier of prefabricated housing materials was forbidden to use the term "Disputes arising from this contract shall, if the seller so desires, be resolved by arbitration according to the law".

What makes this case interesting, is that the Market Court based its injunction on two separate grounds. The second was the supplier's failure to comply with the Arbitration Act and the ensuing deception of the consumer regarding his legal rights. The first ground given by the court was that arbitration procedures are more expensive for consumers than judicial procedures because the Legal Aid Act provides for financial help only in the latter instance. The court was afraid that such clauses would discourage consumers from asserting their rights and from having them legally established. As a result of the court's reliance on this more general reasoning, its decision has an impact exceeding the area covered by para. $3 \mathrm{a}$ of the Arbitration Act. It may suggest that arbitral clauses are unreasonable in all consumer transactions to which the Legal Aid Act applies. The decision is also an

33. The two Supreme Court decisions are discussed by Nils Mangard, Ogiltighet av skiljeavtal i affärsforhallanden, in: Svenk och internationell skiljedom 1981/Arsskrift frân Stockholms Handelskammares Skiljedomsinstitut, Stockholm 1981.

34. Generalklausul i förmögenshetsrätten, SOU 1974: 83, pp. 33-39.

35. SFS 1971: 112, as amended.

36. SFS 1929: 145, as amended. An English translation can be found in Arbitration in Sweden, published by the Stockholm Chamber of Commerce, Stockholm 1977, p. 192-201.

37. SFS 1974: 8.

38. Prop. 1976/77: 110, p. 45.

39. Marknads domstolens avgöranden 1975: 5. 
example of unreasonableness per se of any term which gives the tradesman the unilateral right to call for arbitration. ${ }^{40}$

The effect of consumer protection law on the development of the law as applied between businessmen is obvious ${ }^{41}$, $\mathrm{cf}$. the two Supreme Court cases discussed at the beginning of this paragraph. Moreover, a government commission has recently proposed the enactment of a bill which would extend the jurisdiction of the Market Court to (improper) terms in contracts between business enterprises. ${ }^{42}$

\section{SOME ENGLISH CASES}

Although the United Kingdom has recently enacted a statute on improper contract terms, the Unfair Contract Terms Act, it is not this act which has provided the courts with the possibility of setting aside arbitral clauses. ${ }^{43}$ It is rather the Arbitration Act 1979, which has given rise to some interesting cases. ${ }^{44}$ The Arbitration Act 1979 was intended to change arbitration practice in England. It had been observed that, although many arbitrations were still held in London, other centres such as Paris, Geneva, New York and Stockholm had come to be regarded as more suitable for major international arbitration. The basic reason for this "emigration" of arbitration lay with the British courts" application of the Arbitration Act 1950, under which they exercised wide-ranging powers to supervise arbitration proceedings, particularly through the "case stated" procedure. This procedure allowed either party to request the arbitrator to state a question of law arising in the course of the arbitration for the decision of the High Court. If the arbitrator declined, the requesting party could nevertheless apply to the Court, which almost invariably directed that a special case be stated.

Under the 1979 Act, the "case stated" procedure was abolished. An appeal to the High Court arising out of an arbitration's award was only to be made on a point of law, and such an appeal might be made either with the consent of all parties or where the Court gave leave (subject to an exclusion agreement). Section 1 (4) provides that the Court shall not grant leave unless "it considers that, having regard to all the circumstances, the determination of the question of law concerned

40. UIf Bernitz and John Draper, Consumer Protection in Sweden/Legislation, Institutions and Practice, Stockholm 1981, pp. 238-239.

41. Ulf Bernitz, when discussing the question whether small businessmen might rely on para 36 of the Contract Act, argues that the reflex effects of the new consumer legislation are evident: U. Bernitz, Chapter 8 on Market and consumer law, in: Stig Strömholm, An Introduction to Swedish Law, Deventer 1981, I, p. 231, at 252.

42. Avtalsvillkor mellan närigsidkare, Delbetänkande av Konsumentköpsutredningen, Statens offentliga utredningar 1981: 31, Stockholm 1981. On the subject of arbitration clauses see p. 50 .

43. More in general terms, the virtual absence of reported cases concerned with the Unfair Contract Terms Act is striking. The Act was described by L.S. Sealy, 37 Cambridge Law Journal 15 (1978) as follows: 'Not since the Statute of Frauds three centuries ago has there been an enactment which threatens to have so profound an effect on the law of contract...'

44. Regarding the following text see the instructive note by C.J.B. Bloomfield in International Legal Materials 1981, p. 1099 and also C.M. Schmithoff, in Yearbook Commercial Arbitration V, 1980, pp. 231-239; VI, 1981, pp. 155-161; VII, 1982, pp. 179-188. 
could substantially effect the right of one or more of the parties to the arbitration agreement".

Some cases decided shortly after the 1979 Act entered into force have raised doubts as to whether the Act will achieve this objective. In The Nema Case ${ }^{45}$, the Court of Appeal presided over by Lord Denning MR suggested that in this

- aspect a distinction should be made between "one-off clauses" in a "one-off" contract and arbitral clauses in a standard form. In the Oinoussion Virtue Case $^{46}$, Robert Goff J. ${ }^{47}$ flatly rejected this distinction, but on appeal in The $\mathrm{Nema}^{48}$, the House of Lords, although reproving Lord Denning for his 'somewhat less than tactful phrase' that an arbitrator might just as likely be right as a judge - in fact was probably more likely to be right - upheld his decision. Lord Diplock's views on arbitral clauses in standard contract terms are relevant here. He begins by observing that "the great majority of international maritime and commercial contracts which contain a London arbitration clause . . . are made on standard printed forms on which the particulars appropriate to the contract between the actual parties are inserted, and any amendments needed for reasons special to the particular contract are either made to the printed clauses or dealt with in added clauses, which sometimes may themselves be classified as standard. Business on the Baltic, the insurance market and the commodity markets would be impracticable without the use of standard terms to deal with what are to be the legal rights and obligations of the parties upon the happening of a whole variety of events which experience has shown are liable to occur, even though it be only rarely, in the course of the performance of contracts of those kinds". ${ }^{49}$

Lord Diplock then continues by considering that "when contracts are entered into, which incorporate standard terms, it is in the interests alike of justice and of the conduct of commercial transactions that those standard terms should be construed and treated by arbitrators as giving rise to similar legal rights and obligations in all arbitrations in which the events have given rise to the dispute do not differ from one another in some relevant aspect. It is only if parties to commercial contracts can rely upon a uniform construction being given to standard terms that they can prudently incorporate them in their contracts without the need for detailed negotiation or discussion. Such uniform construction of standard terms had been progressively established up to 1979 , largely through decisions of the courts upon special cases stated by arbitrators. In the result English commercial law has achieved a degree of comprehensiveness and certainty that has made it acceptable for adoption as the appropriate proper law to be applied to commercial contracts wherever made by parties of whatever nationality. So in relation to disputes involving standard terms in commercial contracts, an authoritative ruling of the

45. 1 1980 QB 547; [1980] 3 All ER 117; [1980] 3 WLR 326.

46. [1981] 2 All ER 887.

47. The very same High Court judge, who had already had to decide the Nema Case, before it came before the Court of Appeal.

48. Pioneer Shipping Ltd. v. B.T.P. Tioxide Ltd. (The Nema), [1981] 3 WLR 292, applied also in Italmare Shipping Co. v. Ocean Tanker Co. Inc. (Court of Appeal), [1982] 1 WLR 158.

49. [1981] 3 WLR 292, at 298. 
court as to their construction, which is binding also upon all arbitrators under the sanction of an appeal from an award of an arbitrator that has resulted from his departing from that ruling performs a useful function that is lacking in that performed by the court in substituting for the opinion of an experienced commercial arbitrator its own opinion as to the application of a "one-off" clause to the particular facts of a particular case." 50

Although Lord Diplock does not say so explicitly, it seems clear from his opinion that the maxim of uniformity in construction of standard arbitral clauses may be placed on a higher level than the sacred contra proferentem maxim. ${ }^{51}$

\section{DUTCH IUS CONSTITUENDUM}

To return to Dutch law, I must first briefly outline the law regarding arbitral clauses as it stands. Unlike French law, Dutch law has always been liberal in allowing arbitral clauses. In legal writing it has long been argued that, especially when incorporated in standard contract terms, arbitral clauses should not be considered to apply as automatically as other clauses. A legal basis for this contention was found in Article 170 Grondwet (Constitution) - 'Nobody may against his will be abstracted from the court, which law allots him' - or in Article 620 Wetboek van Burgerlijke Rechtsvordering (Code of Civil Procedure) - 'One may even commit oneself in advance to submit to arbitration conflicts which might arise in the future'. 52

In 1967 the Hoge Raad (Supreme Court) rejected this theory unequivocally. ${ }^{53}$ This decision, however, has not been accepted by all writers ${ }^{54}$ and a counter trend may be observed. There is some evidence that under modern international arbitration conventions, arbitral clauses should be dealt with more strictly than other standard contract terms. ${ }^{55}$ This is also the case with regard to the related choice of forum clauses. ${ }^{56}$ The heaviest attack on the arbitral clause, however, comes from the present government bill on standard contract terms. ${ }^{57}$ This bill

\section{Ibidem.}

51. The maxim verba cartarum fortius accipiuntur contra proferentum is often used in common law to construct standard contract terms against the party who has drafted the terms.

52. See P. Sanders, Aantasting van arbitrale vonnissen, thesis Ley den, Zwolle 1940, pp. 46-47; the same, Dutch national report, in Yearbook commercial arbitration VI, Deventer 1981 , pp. $60-85$.

53. HR 27 October 1967 Nederlandse Jurisprudentie 1968, 3 (Menne v. Van Nunen).

54. See A.R. Bloembergen and W.M. Kleyn, Contractenrecht VII, No. 291.

55. Regarding the possible voidness of a compromissory clause by virtue of art. II/ section 2 of the New York Arbitration Convention, see for example, A.J. van den Berg, The New York arbitration convention of 1958/Towards a uniform judicial interpretation, thesis Rotterdam, The Hague/Deventer 1981, pp. 170-232.

56. See for instance art. 17 EEC Execution Convention and its application by the European Court in Estatis Salotti di Colzani Aimo c.s. v. RÜWA Polsteraimaschinen, [1977] 1 CMLR 345 and Galeries Segura v. Rahim Bonakdarian, [1977] 1 CMLR 361.

57. Bill 16,983. See also the contribution by H. Duintjer Tebbens in this volume. At the end of 1982, the Ministry of Justice published a draft bill on arbitration itself. This draft also refers to arbitral clauses in standard contract terms. According to art. 1000 of the draft, the 
is to be incorporated into the New Civil Code, which presumably will enter into force in 1985. The bill provides for a control system of standard contract terms, which is quite similar to the German system: one of the five gerechtshoven (courts of appeal), i.e., the one in The Hague, will be given the power to issue an injunction with regard to any further use of standard contract terms which contain unreasonably onerous clauses. The injunction will be issued only upon the request of a trade organisation or a consumers' organisation (Article 6.5.2A.6, para. 2). The general clause, which should provide a guideline to the court and to the parties concerned (Article 6.5.2A.2, para. 2 under a) and which shall also be applicable in individual disputes, is supplemented in consumer contracts by two lists of clauses, which will either be held to be unreasonably onerous and therefore null and void (Article 6.5.2A.3), or be held to be unreasonably onerous unless the contrary appears to be the case (Article 6.5.2A.4). Among the clauses which are listed in the 'black list' of Article 6.5.2A.3 is the arbitral clause, at least the arbitral clause which does not leave the other party the possibility to opt for the ordinary court once the conflict has arisen.

An earlier draft outlawed the standard arbitral clause outright, but apparently the government paid heed to the comments of the construction trade in particular with regard to this clause. It is apparent that Dutch trade interests are very concerned about the present prohibition article, even though it is somewhat diluted, and the outcome of the parliamentary debate which will ensue is uncertain.

D In my opinion the present government approach is correct. Arbitration and other methods of the settlement of disputes out of court are not inherently bad; often the advantages outweigh the disadvantages. But if arbitration is beneficial to both parties, it should be able to sell itself. It should not be imposed upon one party, who is unaware of the arbitral clause.

If, under special circumstances, an arbitral clause should be made binding without the consumer being offered a possibility to take the case to court, the bill provides for a procedure to arrive at such a result. Under Article 6.5.2A.5, para. 4 both of the lists of clauses may be set aside, insofar as a consumer's organisation declares a clause to be not unfair. This leaves room for negotiation - the principal aim of the bill. It should also be observed that the scope of the two lists is limited to consumer transactions and that the bill contains several exceptions. Thus, the kantongerecht case which was cited in the first paragraph might fall under two exceptions: first, it is not clear whether it was a consumer contract and second, being a shipping contract, it would fall under the exception of Article 6.5.2A.11, para. 2. Both exceptions would result only in the two lists of clauses not being directly applicable. This would not prevent a court from applying the general clause of Article 6.5.2A.2, which in turn might lead to the avoidance of the arbitral clause, even in a commercial contract. The Swedish experience may turn out to

existence of an arbitration agreement shall be proven by a document. This includes a document issued by one of the parties which refers to standard contract terms providing for arbitration'. Although this provision does not appear to be exactly in line with the government bill on standard contract terms, it is not clearly in conflict with the proposed art. 6.5.2A.3 either. 
provide some guidelines to Dutch courts regarding the way in which this discretionary power should be used.

As to the construction of standard arbitral clauses, or rather standard contract terms in general, the question has been raised in Dutch legal literature whether any importance should be attached to the avowed wish of trade and industry to have their standard contract terms applied in a uniform way. This wish may be thwarted by other construction maxims, such as the contra proferentem rule. When a private party comes across standard contract terms, which have been drafted bilaterally by two organisations, neither of which, however, can be deemed to represent the said party, the two constructions may result in conflicting outcomes. In a recent report it is argued that in such a case the uniformity of construction should prevail. ${ }^{58}$ Lord Diplock's opinion in The Nema Case may contribute to a better understanding of this argument.

58. Rapport (see footnote 18), p. 56. 